\title{
休憩空間での昼光曝露が執務空間での覚醒水準と作業成績に及ぼす影響 EFFECTS OF DAY-LIGHT EXPOSURE IN RESTING SPACE ON AROUSAL LEVEL AND PERFORMANCE IN WORK PLACE
}

\author{
吉岡陽介*, 宗方 淳**, 川瀬貴 晴** \\ Yohsuke YOSHIOKA, Jun MUNAKATA and Takaharu KAWASE
}

\begin{abstract}
An experiment was performed to clarify effects of intermittent daylight exposure in a resting-space on arousal level and taskperformance in work place. Daylight flowing into the resting-space was controlled with window-blinds. Results indicated, 1) during two working sessions, 11:00-12:00 and 16:00-17:00, the arousal levels analyzed from the frequency of blink burst significantly decreases at the circadian condition more than the non-circadian condition. 2) At some working sessions of the circadian condition, the ratio of correct answer for "Arithmetic", one of computer tasks, significantly decreases after the resting time more than the one before the resting time.
\end{abstract}

Keywords: Resting Space, Daylight Exposure, Task-Performance, Blink Burst, Circadian Lighting: 休㮩空間，昼光曝露，作業成績，瞬目群発，サーカディアン照明

\section{1 研究背景}

\section{1 昼光利用サーカディアン照明}

午前中に高照度の光を浴びることによって、ホルモン分泌や体温 変化などを調節する概日性の生体リズムを、より自然な状態に保つ ことができる 1)。昼行性の哺乳類である人間に本性的に具わるこの 特性を利用し、積極的に生体リズムをコントロールしようとする照 明技術を「サーカディアン照明」と呼ぶ2)。

サーカディアン照明の効果は、さまざまな研究分野において実証 されており、実際の施設への導入事例もしだいに増えてきている。 例えば国内では、生体機能が弱体化する傾向にある高齢者や、昼光 を浴びる機会の少ない病院内療養者の生体リズムを改善する手法 として導入された事例 3,4)が報告されている。また海外では、原子力 発電所など 24 時間の有人管理が必要な施設において、夜間勤務者 の覚醒水準をリブートすることを目的に、意図的にタイムシフトし て導入された事例などが報告されている5)。

こうした高照度光による生体リズムのコントロールは、一般的な 執務環境においても有効である。現代社会に生きる私たちは、甚大 なエネルギー消費によって自然の昼夜とは全くの関係ないサイク ルで活動することができる。しかし、利便性とともにもたらされる 生活サイクルの乱れは、生物としての人間がもつ生来的なリズムを 狂わせ、多くの肉体的・精神的な疾患の要因となっている。

オフィスなどの執務環境にサーカディアン照明が導入され、その 効果を十全に発揮すれば、日中の覚醒水準が高まることによる生産
性の向上はもとより、夜間における充分な睡眠が確保できることに よる疲労回復やストレスの軽減も期待できる。中長期的視点に立て ば、従業員の健康促進から病欠率の減少に繋がり、ひいては就業満 足度の引き上げにも少なからず寄与することになるだろう。

こうした展望のもと、我々がこれまで探求してきたのが、「昼光」 を利用したサーカディアン照明の可能性である 6-9)。

人工光によるサーカディアン照明では、高照度光を照射するため の設備投資や消費エネルギーが必然的に大きくなる。そのため一般 的な執務環境にシステムとしてサーカディアン照明を導入するに は、経済的なハードルがきわめて高かった。

このハードルに対する解決策として有力視されるのが、「昼光」の 利用である。執務環境内に流入する昼光を適切に統制することがで きれば、人工光によるサーカディアン照明と同様の照度変化を作り 出すことは可能である。昼光利用サーカディアン照明であれば、ロ ーコスト・低環境負荷でありながら、大規模な工事なども必要なく、 誰もが比較的容易に導入することができる。被験者実験を通してそ の効果を定量的に検証し、導入によるメリットとともに、デメリッ 卜の有無をも明確に提示することで、生活技術としてのサーカディ アン照明の普及に貢献することができるだろう。

\section{2 休䡯空間へのサーカディアン照明の適用}

執務空間の環境質が作業効率に影響を与えることは、ワークプレ イス・プロダクティビティを扱った多くの既往研究において指摘さ れている。ワークプレイス・プロダクティビティとは、生産性を指
* 千葉大学大学院工学研究科建築·都市科学専攻 助教・博士 (工学)

** 千葉大学大学院工学研究科建築·都市科学専攻 教授・博士 (工学)
Assist. Prof., Division of Architecture and Urban Science, Graduate School of Engineering, Chiba University, Dr.Eng.

Prof., Division of Architecture and Urban Science, Graduate School of Engineering, Chiba University, Dr.Eng. 
標として、執務空間の環境質を定量的に評価しようとする試みであ り、特に空気質, 温熱環境, 音環境、そして光環境について、それ ぞれの質が低下すると作業効率も顕著に低下寸ることが報告され ている ${ }^{10-15)}$

ここでいう作業効率とは、情報の定型的な処理にかかる時間効率 や正確性を指し示すものである。ワークプレイス・プロダクティビ ティを、その上層から「知識創造」「知識処理」「情報処理」の三つ の階層に分類する「知的活動の三階層モデル ${ }^{16)} 」 に$ 照らすならば、 上記の先行研究における検証は、最下層の「情報処理」における能 力が、環境質に大きく影響されることを示していることになる。

本研究も、サーカディアン照明による照度変化が、単純な情報処 理課題における作業効率に与える影響を検証するものであり、その 意味では、一連のプロダクティビティ研究の中で、「情報処理」の階 層における生産性を扱った研究の一つとして位置づけられる。

ただし、本研究においてサーカディアン照明を適用するのは、「休 悡空間」に対してである。実際に作業を行う「執務空間」に、直接 的にサーカディアン照明を導入することは、想定していない。サー カディアン照明がその効果を顕在化させるには、20001x を超える照 度が必要となる ${ }^{17-20)}$ 。執務空間の照度としては過剩であり、長時間 曝露によって、かえって作業に支障をきたす恐れさえある。

一方で、これまでのサーカディアン照明の研究から、照度設定が 適切であれば、それほど長時間の曝露を必要としないことも示され てきた ${ }^{4,9)}$ 。ここで本研究では、業務間の一時的な滞在場所である休 馝空間に対して、昼光利用サーカディアン照明を適用することを検 討寸る。短時間の昼光曝露を複数回に分けて反復することで、どの ような効果が期待できるか。逆に執務空間での作業に弊害を及ぼす ことはないか。こうした設問に回答するため、短時間の昼光曝露が 作業成績や覚醒水準に及ぼす影響を検証する実験を計画した。

プロダクティビティという言葉が広く認知されるようになって久 しい。しかし、これまでのこの研究分野の流れを俯瞰すると、執務 空間の生産性を増進することにのみ注力しすぎているようにも見 える。生産性の増進を突き詰めたどんなに優れた執務空間であって も、常時その環境に晒され続ければ、勤続疲労などの事由から生産 性の低下がいずれ訪れることになる。

プロダクティビティを補完する概念として、「リフレッシュアビリ ティ(休息性能指標)」とでも呼心゙るような、休悡空間を計画するた めの新しい評価指標の提起が必要ではないだろうか。執務空間のプ ロダクティビティを向上させると同時に、そのカウンターバランス として休憩空間のリフレッシュアビリティを担保し、それぞれを調 和的、相補的に配置することで、はじめて持続可能な形での生産性 の増進が期待できると考えられる。

\section{2 研究目的}

本研究では、休息空間における短時間の昼光曝露が、執務空間で の覚醒水準と作業成績に及ぼす影響を、被験者実験を通して明らか にする。

測定指標は、群発性の瞬目の発生頻度から推定する覚醒水準、パ フォーマンス測定用の作業課題に対する作業成績、の 2 つである。 2 つの指標値の検証を通して、休䚐空間など長時間滞在しない場所 における、昼光利用サーカディアン照明の適用の是非を探る。

\section{実験方法}


一日中、作業室のパソコンに向かって作業を続けてもらった。休䐣 室の照明条件は、昼光によって午前中をメインに高照度環境にした 「サーカディアン条件」と、人工光によって常時一定の照度環境と した「非サーカディアン条件」の 2 条件とし、各条件での被験者の 生理的変化や作業時のパフォーマンスの変動を測定し比較する。

\section{1 実験期間と被験者}

実験は千葉大学にて 4 年に分けて実施した。実験地の気候から、 年間でも降雨量が少なくかつ十分な日照を確保できる 3 月上旬を実 験時期とした。(表 1)。

被験者は 20 代大学生 20 名（男性 12 名、女性 8 名）であり、全被 験者が延べ 5 日間の実験に参加した。被験者には、実験開始の一週 間前から後述のリセット期間を含む全行程において、強い日照のも とでの長時間の屋外活動や、カフェインなどの刺激物の摂取を避け、 かつ夜 12 時から朝 7 時までの間は確実に就床するように指示した。 また実験初日には風邪などの自覚症状を申告させ、健康状態に問題 がないことを確認した上で、実験を実施に移した。

なお本実験は千葉大学工学部生命倫理委員会の承認のもと実施 している。被験者には、本実験が各種の生理測定を伴うものである ことを事前に説明し、個人情報管理の徹底を前提に、実験参加ある いは継続の意思を折々に確認している。

\section{2 実験空間}

南向きの大きな空をもつ一室を実験室とした（図 1)。実験室の大 きさは、奥行 $8.1 \mathrm{~m}$ 、幅 $6.9 \mathrm{~m}$ 、天井高 $2.85 \mathrm{~m}$ である。空の横幅は $6 \mathrm{~m}$ 、 高さは腰壁上端 $0.85 \mathrm{~m}$ から梁下 $2.8 \mathrm{~m}$ まで、空の外に天空光を大き く遮るような建物や樹木はない。室内側には調光用の電動ブライン ドが設置されており、スラットの角度を遠隔操作することで室内の 照度を自在に調節寸ることができる。また電動ブラインドのさらに 内側には、遮光率 $99.99 \%$ の遮光カーテンが据えられている。

表 1 各実験日程における天候と外気温

\begin{tabular}{|l|cc|ccc|}
\hline & \multicolumn{2}{|c|}{ Non-Circadian } & \multicolumn{3}{|c|}{ Circadian } \\
\hline Experimental Period 1 & $2008 / 3 / 9$ & $3 / 10$ & $2008 / 3 / 1$ & $3 / 2$ & $3 / 3$ \\
Daytime Weather & Sunny & Rainy & Sunny & Sunny & Sunny \\
High/Low Temperature & $15 / 3$ & $12 / 7$ & $14 / 5$ & $12 / 5$ & $15 / 5$ \\
\hline Experimental Period 2 & $2008 / 3 / 14$ & $3 / 15$ & $2008 / 3 / 6$ & $3 / 7$ & $3 / 8$ \\
Daytime Weather & Cloudy & Sunny & Cloudy & Sunny & Sunny \\
High/Low Temperature & $16 / 9$ & $18 / 12$ & $13 / 3$ & $14 / 4$ & $13 / 4$ \\
\hline Experimental Period 3 & $2008 / 3 / 4$ & $3 / 5$ & $2008 / 3 / 11$ & $3 / 12$ & $3 / 13$ \\
Daytime Weather & Sunny & Cloudy & Sunny & Sunny & Sunny \\
High/Low Temperature & $12 / 5$ & $11 / 4$ & $16 / 5$ & $13 / 8$ & $15 / 5$ \\
\hline Experimental Period 4 & $2009 / 3 / 6$ & $3 / 7$ & $2009 / 3 / 1$ & $3 / 2$ & $3 / 3$ \\
Daytime Weather & Rainy & Cloudy & Cloudy & Sunny & Sunny \\
High/Low Temperature & $11 / 6$ & $16 / 10$ & $8 / 5$ & $11 / 4$ & $6 / 2$ \\
\hline Experimental Period 5 & $2009 / 3 / 14$ & $3 / 15$ & $2009 / 3 / 8$ & $3 / 9$ & $3 / 10$ \\
Daytime Weather & Cloudy & Rainy & Cloudy & Sunny & Sunny \\
High/Low Temperature & $16 / 11$ & $13 / 5$ & $9 / 8$ & $13 / 8$ & $17 / 8$ \\
\hline Experimental Period 6 & $2009 / 3 / 4$ & $3 / 5$ & $2009 / 3 / 11$ & $3 / 12$ & $3 / 13$ \\
Daytime Weather & Rainy & Sunny & Sunny & Sunny & Cloudy \\
High/Low Temperature & $8 / 1$ & $13 / 4$ & $12 / 5$ & $12 / 4$ & $14 / 5$ \\
\hline Experimental Period 7 & $2010 / 3 / 8$ & $3 / 9$ & $2010 / 3 / 3$ & $3 / 4$ & $3 / 5$ \\
Daytime Weather & Cloudy & Rainy & Sunny & Cloudy & Sunny \\
High/Low Temperature & $12 / 3$ & $11 / 3$ & $14 / 3$ & $11 / 5$ & $17 / 5$ \\
\hline Experimental Period 8 & $2010 / 3 / 1$ & $3 / 2$ & $2010 / 3 / 10$ & $3 / 11$ & $3 / 12$ \\
Daytime Weather & Cloudy & Cloudy & Sunny & Sunny & Sunny \\
High/Low Temperature & $15 / 4$ & $9 / 4$ & $14 / 4$ & $14 / 5$ & $15 / 4$ \\
\hline Experimental Period 9 & $2010 / 3 / 6$ & $3 / 7$ & $2010 / 3 / 13$ & $3 / 14$ & $3 / 15$ \\
Daytime Weather & Rainy & Cloudy & Sunny & Cloudy & Sunny \\
High/Low Temperature & $12 / 11$ & $9 / 7$ & $20 / 13$ & $15 / 7$ & $16 / 7$ \\
\hline Experimental Period 10 & $2011 / 3 / 1$ & $3 / 2$ & $2011 / 3 / 8$ & $3 / 9$ & $3 / 10$ \\
Daytime Weather & Cloudy & Sunny & Sunny & Sunny & Sunny \\
High/Low Temperature & $11 / 5$ & $10 / 5$ & $11 / 2$ & $12 / 3$ & $10 / 2$ \\
\hline
\end{tabular}




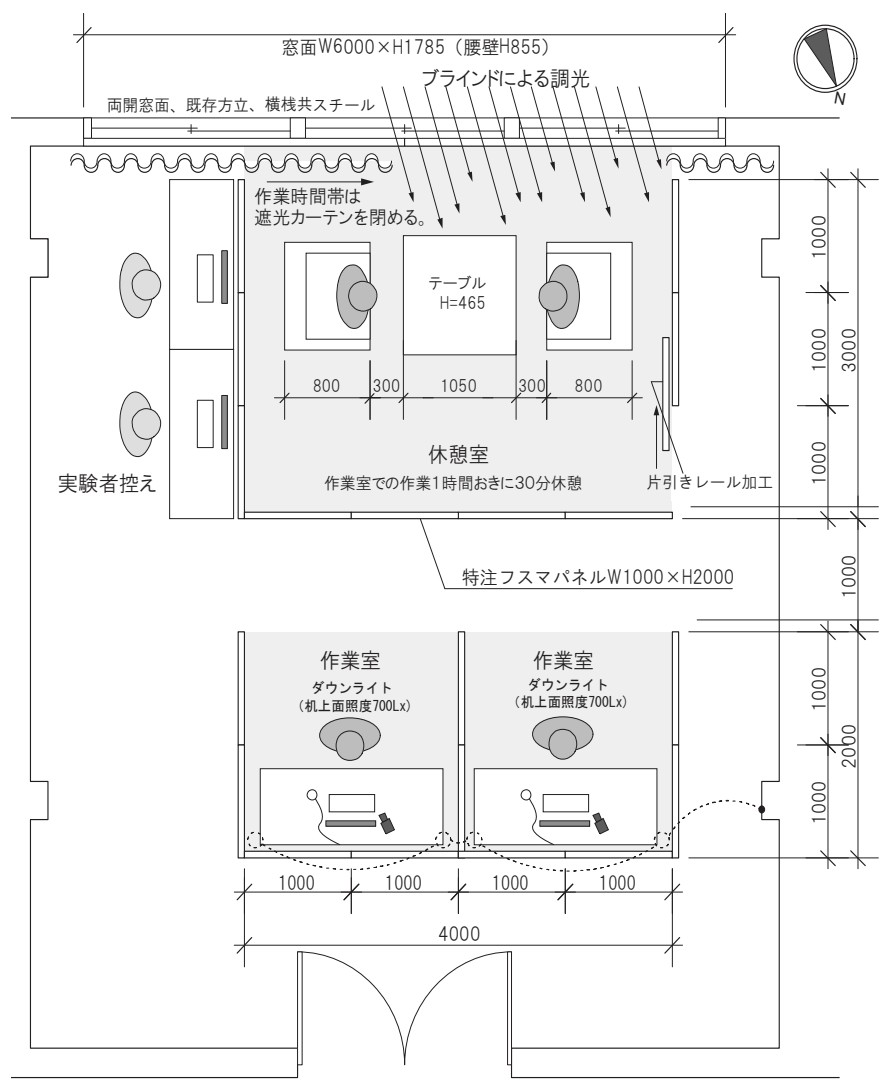

図 1 実験空間の平面図

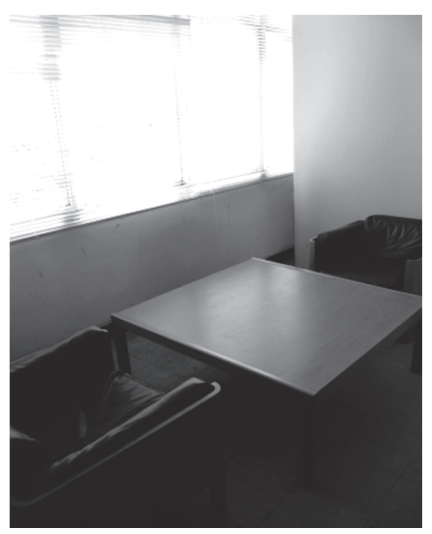

休䡯室

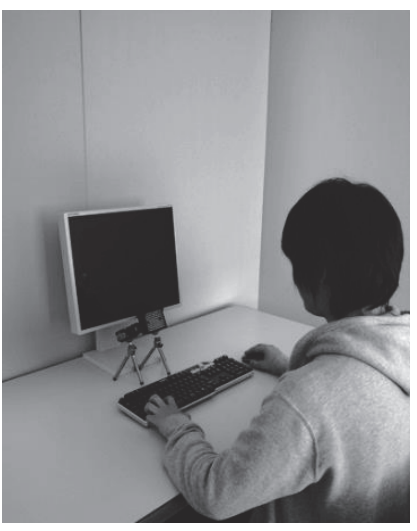

作業室

図 2 実験空間の様子

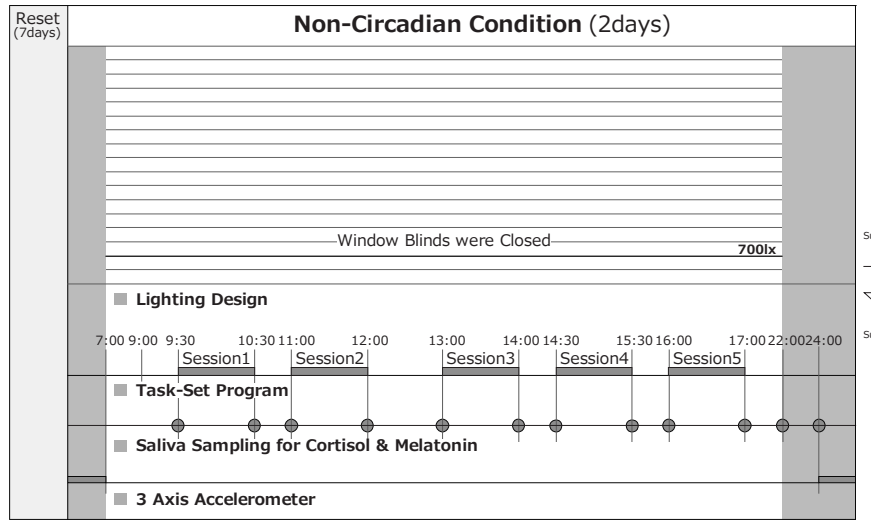

図 3 サーカディアン条件および非サーカディアン条件における照度変化と各種計測の実施タイミング
この実験室を空側と奥側に二分し、それぞれのスペースに高さ $2 \mathrm{~m}$ の灰色のパネルを用いて休憩室と作業室を仕切った（図 1、図 2)。

休㮩室は広さ $4 \mathrm{~m} \times 3 \mathrm{~m}$ の一室とし、 $4 \mathrm{~m}$ の長辺側に空面がくるよう に、密面以外の三方をパネルで囲っている。また空面から $1 \mathrm{~m}$ 離れ た位置にローテーブルを一つ、それを挟むように一人がけソファ二 脚を設置し、被験者二人が同時に寛ぐことができる設えとした。

一方、作業室は $2 \mathrm{~m} \times 2 \mathrm{~m}$ のブースを二つ設け、被験者それぞれが 個別に作業に従事できるようにした。各ブースには机と椅子が設置 され、机上には19 インチ液晶ディスプレイとキーボード、マウスが 置かれている。ディスプレイは休您室裏側に設けられた実験者スペ ースのワークステーションと直結しており、作業時間中は、実験者 によって統制された作業課題が、常時提示されている。

実験中、被験者は作業室と休㮩室とを定期的に行き来し、ディス プレイ上での作業遂行と、休㮩室での休嚊取得とを交互に繰り返す。 実験室内の気候は室温 $24 \pm 0.5^{\circ} \mathrm{C}$ 、相対湿度 $55 \pm 5 \%$ に設定した。

\section{3 実験行程}

各実験日において午前 9 時に実験室に集まった被験者らは、まず

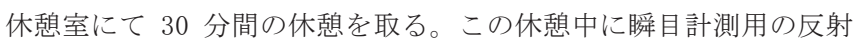
マーカの貼付けなどの準備を済ませ、午前 9 時半よりそれぞれの作 業室において 1 時間の作業セッションに従事する(Session1)。その後 また休毠室にて 30 分間の休数を取り、再び 1 時間の作業セッショ ン（Session2）に戻る。この流れを一日に 5 回繰り返すことで、被験 者は、 9 時半から 17 時までの間に 5 つの作業セッションに従事する

(図 3)。Session2 終了後の休悡時間は 1 時間に延長し、実験者が 用意した低刺激の昼食と適量の水分を摂取してもらう。

なお本実験では、瞬目や作業成績の計測と並行して、唾液中ホル モン分泌量計測、加速度計による夜間睡眠効率の計測も行っている。 これらの計測結果については別の報告に譲るが、実験の全容を明示 するため、図 3 には各種計測の実施タイミングを全て記載している。

\section{4 照明条件}

全実験期間を通して、作業セッション中は常に遮光カーテンを閉 め切り、昼光が実験室内に入らないようにした。その上でそれぞれ の作業室の机上面照度が、液晶ディスプレイからの照射光の影響も 含めて 7001x となるように、天井照明（蛍光灯:5000K）の光量を調 整した。ディスプレイ輝度は、作業中の被験者の目線位置への照射 光量が、鉛直面照度で $51 \mathrm{x}$ 以下になるよう設定した。なお天井照明 を含めた被験者目線位置の鉛直面照度は、ディスプレイの点灯・消 灯に大きな影響を受けずおおよそ $3201 \mathrm{x}$ 程度であった。

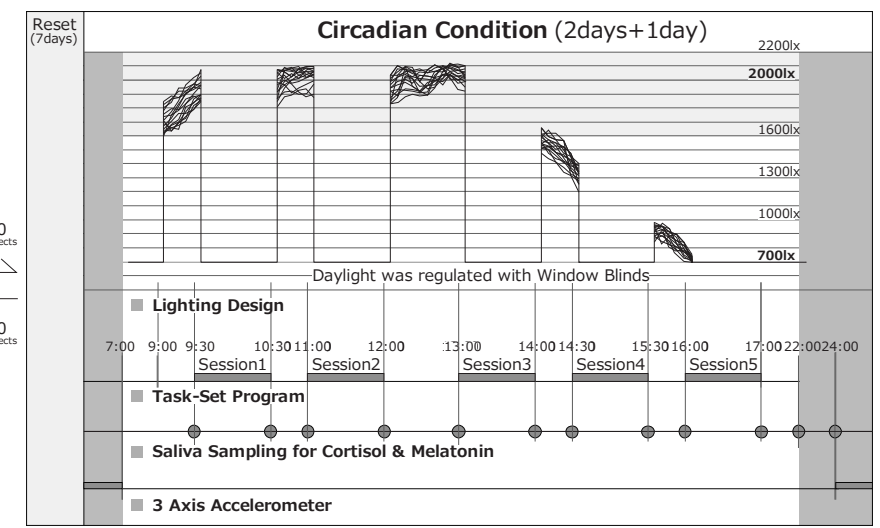


一方、休㮩中の休数室については、昼光を流入させた「サーカディ アン条件」と、昼光を排除した「非サーカディアン条件」の 2 条件を 用意し、条件間の被験者の作業成績や生理指標の変化を比較する。 延べ 5 日間ある実験期間を二つに分け、3 日間をサーカディアン 条件、残りの 2 日間を非サーカディアン条件の実施期間とする。数 日間かけて高照度光を浴び続けることの効果を検証するため、サー カディアン条件のみ一日延長して、3 日間の実験期間とした。二つ の条件間には最大一週間のリセット期間を設け、実施順序も被験者 半数ごとに入れ替えている。

非サーカディアン条件の二日間では、作業セッション中と同様に 遮光カーテンを閉め切り、天井の蛍光灯照明 (5000K) のみで、ロー テーブル中央の照度が 7001x になるように調整した (図 3 左)。なお このとき被験者の目線位置における鉛直面照度は約 $2501 \mathrm{x}$ であった。

一方、サーカディアン条件の三日間では、休憩時間中の休憩室内 に、朝に最も明るく夕方に向けて徐々に暗く、というサーカディア ン照明特有の照度変化をつくりだす。休䄭室各所に設置した照度計 のうち、ローテーブル中央の照度計の数值を制御代表值とし、午前 中の休毠時間には 2000lx を中心として 1600 lx〜2200lx の範囲で推 移するように制御し、午後からは Session5 開始時にちょうど 700lx になるように線形に照度を下げていった（図 3 右）。

ソファ着座時の被験者目線位置（高さ約 $700 \mathrm{~mm}$ ) の鉛直面照度は、 この制御代表值と連動して推移し、制御代表值が 20001x の時、約 18001x～2200lx で維持されていた。本論では、被験者の目線位置に おいて制御代表值と同程度の鉛直面照度があったものとして検証 を行う。

\section{5 作業課題}

各作業セッションにおいて被験者は、ディスプレイ上に提示され る3種類の作業課題、「数列穴埋め (Arithmetic)」「記憶 (Memory)」 「語順並べ替え (Word Order)」に従事した。これらの作業課題は、 Shimodaら ${ }^{21}$ によって開発されたタスクセットプログラム、「CPTOP2 (Cognitive Performance Test for Office Productivity 2)」の中から、事前 の検証によって実験条件によるパフォーマンスの変化が生じやす いと判断した作業課題を抜粋したものである。CPTOP2はオフィス ワーカの知的生産性を定量的かつ簡便に評価する方法として開発 されたもので、本来は上記の 3 種類に、独創性を評価する「ブロック 組み立て」を加えた、4種類の作業課題から構成されている。

「数列穴埋め (Arithmetic)」は、提示された数列の空白箇所にあ てはまる数字を類推する作業課題で、数学的推論の能力を評価する。 等差数列、等比数列、フィボナッチ数列のいずれかのオーダーに従 った $5 つ の$ 数字が横に並び、久落している 6 つめの数字を、画面下 に提示される 4 つの選択肢からマウスクリックで選ぶ。

「記憶 (Memory)」では、図形の状態遷移のルールを読み取り記

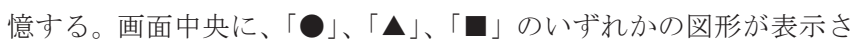
れており、その下の「1」、「2」、「3」のボタンをクリックすると、図 形の形状が課題ごとに決定されるルールに従って変化する。「○」が 提示されているときに「1」を押せば、「○」は「ム」に変化し、「2」 を押せば「の」は「○」のまま、「3」を押せばまた「の」は「、 に変化する、といった状態遷移のルールを課題ごとにすべて見出し、 記憶することが求められる。記憶したルールを画面左の $3 \times 3$ のブ ロック表に埋め込むことで一つの試行が完了する。
「語順並べ替え(Word Order)」は、複数の語句カードを自然な文章 に並べ替える作業課題で、言語能力を評価する。ランダム提示され た語句カードを正しい語順でクリックし解答する。一箇所でも語順 に誤りがあれば解答全体が誤答と判別される。難易度に差が生じな いよう、並べ替え後に連続するカードは近接して提示していない。

いずれの課題においても、回答を確定すると、回答の正誤にかか わらず直ちに次の問題が提示され、10 分間の制限時間いっぱいまで 課題への回答が繰り返し要求される。

被験者は、作業セッションが始まると、まず「数列穴埋め」、「記 憶」「語順並べ替え」の順で各 10 分間ずつ作業課題に取り組み、 3 種 類の課題を一巡し 30 分が経過したところで、今度は逆の順番でさ らに 10 分間ずつ 3 種類の課題に取り組む。最後の「数列穴埋め」の 10 分間が経過した時点で、ちょうど 1 時間の作業セッションが終了 するようにデザインしている。

\section{6 瞬目計測}

短時間にいくつもの瞬目が発生する現象を瞬目群発 (b1ink burst) と呼ぶ。保坂らは、瞬目群発の増加が覚醒水準の低下と相関が高い ことを明らかにした ${ }^{22)}$ 。この研究成果を踏まえて、本研究では、瞬 目群発の発生頻度を覚醒水準の指標として用いる。また休㮩前後に おける作業成績の変動と、この覚醒水準の変動との関係についても 本論では一部言及する。

作業課題に従事している間の被験者の瞬目頻度を計測するため、 モーションキャプチャ用の高精細カメラ（PENTAX；GE-60）と赤外線 照射装置（サンメカトロニクス；K-Light）を、作業室の机の上に、 ディスプレイの下端から被験者側に向けて設置した（図 2)。カメラ 映像は、実験者控えスペースに置かれたワークステーションに直送 され、リアルタイムで画像解析される。被験者の上下のまぶたには 赤外線を反射する特殊マーカが貼り付けられており、高精細カメラ の映像からマーカどうしの 2 点間距離の伸縮を数量化し、被験者の 瞬目パターンとして抽出する。

\section{4 実験の結果と考察 \\ 4. 1 瞬目群発の発生頻度}

各条件における瞬目群発を計上し、その発生頻度を比較した（図 4)。本研究では保坂ら ${ }^{22)}$ の定義を踏襲し、一秒未満の間隔の瞬目 が 3 回以上（間隔でカウントした場合は 2 回以上）繰り返された場 合、その連続する複数の瞬目を一つの瞬目群発と定める。

計測結果の全体的な傾向としては、どの照明条件においても Session3 における群発瞬目の発生頻度が最も低く、Session5 にお ける群発瞬目の発生頻度が最も高いことが見てとれる。

正規性と等分散性を確認した後、セッション・照明条件を要因と して分散分析をおこなったところ、二要因およびその交互作用にお いて帚無仮説が棄却された。そこで単純主効果を確認したのち各要 因についてボンフェローニ法による多重比較検定を行った。本論で は以降、同様の手順で統計分析を進め、有意差の示された条件間に ついてはデータの全体的性向を明示するため全て記載する

多重比較の結果、Session2 とSession5 のそれぞれにおいて、サ 一カディアン条件よりも、非サーカディアン条件のほうが瞬目群発 の発生頻度は有意に高いことがわかった（Session2 (CircadianDay1 /Non-CircadianDay1:p<0.001, CircadianDay2/Non-CircadianDay 
$2: \mathrm{p}<0.001)$, Session5 (CircadianDay1/Non-CircadianDay1:p $<0.00$

1, CircadianDay2/Non-CircadianDay2: p<0. 001))。特に Session1 においてどの照明条件でも群発瞬目の発生頻度は同じ程度なのに 対し、Session2ではサーカディアン条件では減少し、非サーカディ アン条件では増加するという対照的な性向を見せている。非サーカ ディアン条件のSession2 と Session5 において、被験者の覚醒水準 が低下していることが示唆される。

図 5 は休慜の直前と直後に実施された「数列穴埋め」課題中（10 分間）の、被験者の群発瞬目の発生頻度を抽出し、休款の前後にお ける変化を比較したものである。興味深いことに、総じて群発瞬目 の発生頻度は、休覟直前よりも休蒩直後のほうが高くなる傾向にあ った。休㮩前よりも休螅後のほうが、覚醒水準は低下寸る傾向にあ ることが示唆される。またその休款前後の変化は、非サーカディア ン条件一日目の 4 回目の休䕀、非サーカディアン条件二日目の 2 回 目の休㮩の前後において、統計的に有意な差をもって反転している。

\section{2 作業課題の成績}

CPTOP2 の各作業課題に対する成績を、単位時間あたりの正答数 として算出し比較検証する。作業成績は概ね、実験開始当初におい て漸次的に向上し、試行回数を重水習熟が進むにつれて次第に一定 の值に落ち着くという性向を見せる。本研究では、下田ら ${ }^{23)}$ による 習熟モデルを参考に、被験者ごとの作業成績の時系列変化から、最 小二乗法により対数近似曲線を導出し、この近似曲線を新たな軸と

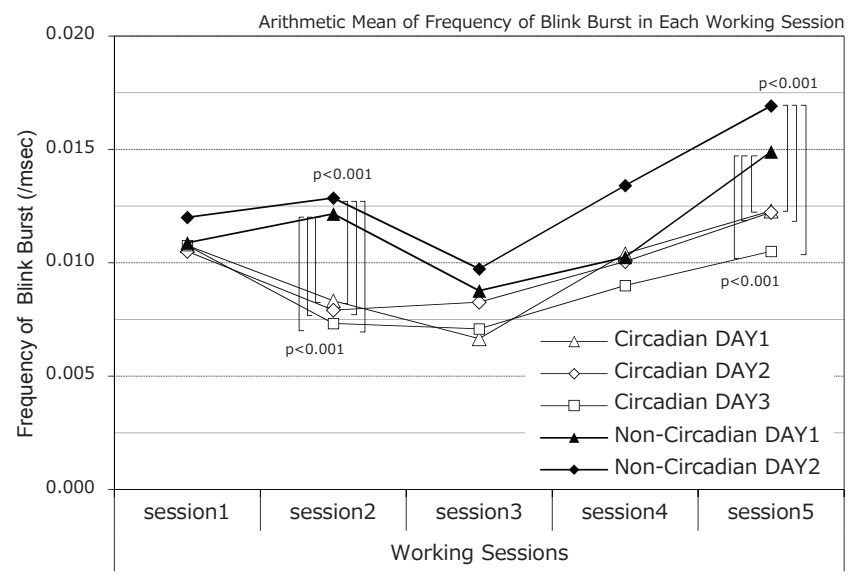

図 4 各条件における瞬目群発頻度の推移(相加平均)

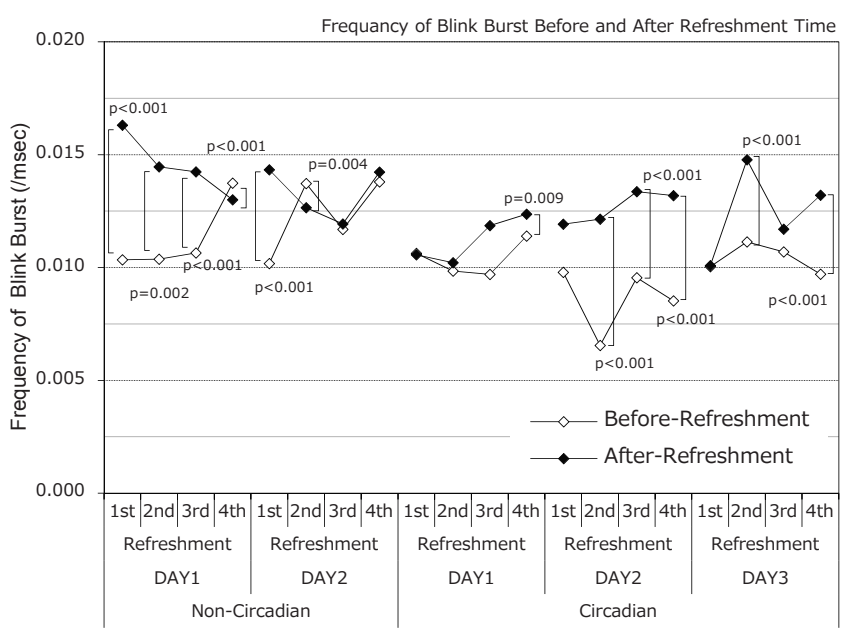

図 5 休䕀前後における瞬目群発頻度の変化（相加平均）
して各データを再配置することで、それぞれの作業成績に対する習 熟の効果を補正することとした。

補正後のデータを分散分析にかけ、補正前に検出されていた時間 経過を要因とする変動が、解消されていることを確認した。また同 時にこの補正で、平均值の差として抽出される個人による能力の差 も検出されなくなっている。

\section{2.1 「数字穴埋め (Arithmetic)」の成績}

図 6 に各実験日における「数列穴埋め(Arithmetic)」の成績の推 移を示す。どの実験条件でも、Session1 から Session3（あるいは Session2）に向けて作業成績は一端向上し、その後 Session4、5に かけて次第に下降するという性向を見せている。

実験条件・セッションを要因とした分散分析からはセッション間 の比較においてのみ帰無仮説が棄却された。そこでセッションを要 因とした多重比較検定を行った結果、実験条件全体をとおして Ses sion3 の作業成績が Session1, Session5 の作業成績よりも有意に高 くなっていることが確認された（Session1/Session3:p<0.001， Ses sion3/Session5:p<0.001)。

また図 7 に「数列穴埋め(Arithmetic)」の休㮩前後における作業 成績の変化を示す。「数字穴埋め (Arithmetic)」に関しては、各休 憩の直前と直後に同じ 10 分間ずつ実施するように計画している。 そのため双方を個別に計上し比較することで休数の効果を検証す ることができる。

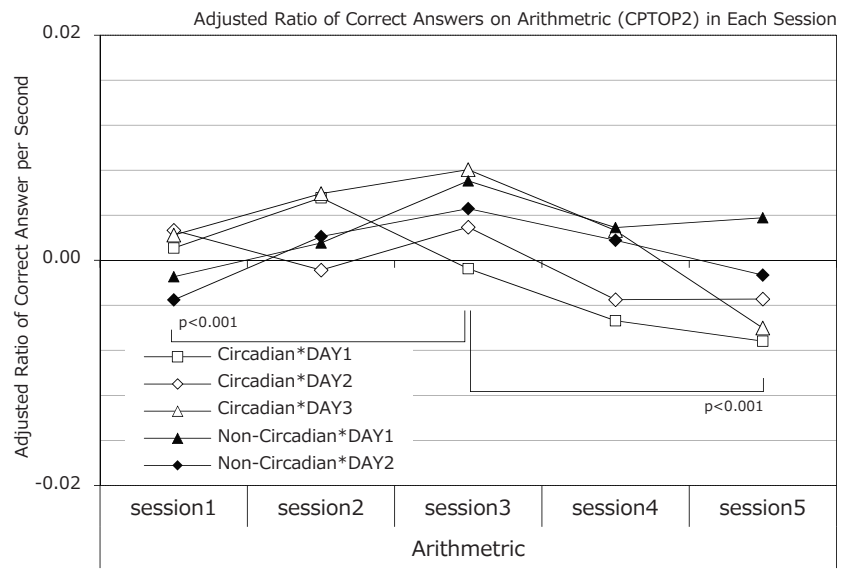

図 6 「数字穴埋め (Arithmetic)」課題の成績推移

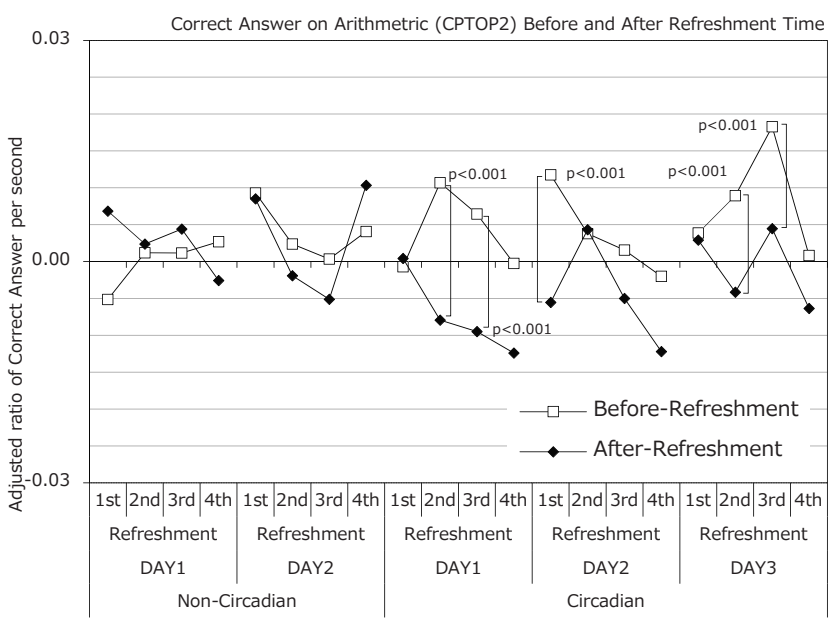

図 7 休顋前後の「数字穴埋め (Arithmetic)」の成績推移 
分散分析後の多重比較検定によって、休㮩前後で有意な差が生じ ていることが認められたのは、サーカディアン条件一日目の第二、 第三休䕀、サーカディアン条件二日目の第一休款、サーカディアン 条件三日目の第二、第三休䕀である (CircadianDay1(2nd Refreshm ent: p<0.001, 3rd Refreshment: p<0.001), CircadianDay2(1st Refreshment: p<0.001), CircadianDay3(2nd Refreshment: p<0.0 01, 3rd Refreshment: p<0.001))。

上記の検定結果を概観すると、有意差が生じていたのはいずれも サーカディアン条件であり、かつ休款前よりも休顋後の方が作業成 績は低くなることが示されている。「数列穴埋め (Arithmetic)」の ような、演繹的思考が必要とされる作業課題に対しては、高照度光 曝露下での休憩は、かえって休䕀後の作業成績を低下させてしまう 効果を持つことが示唆される。出現のタイミングが厳密に重なるわ けではないが、瞬目群発の発生頻度において確認されたサーカディ アン条件下での休顋後の覚醒水準低下と符合寸る結果である。

\section{2. 2 「記憶 (Memory)」の成績}

図 8 に「記憶(Memory)」の成績の推移を示す。サーカディアン 条件三日間における Session3 の作業成績が、他のセッションでの 作業成績に比べて急激に低下しているように見える。「記憶(Memor y)」のような記憶能力を必要とするような作業に対して、特に Sess ion3 の時間帯で、高照度光曝露下での休款が負の影響を与えている

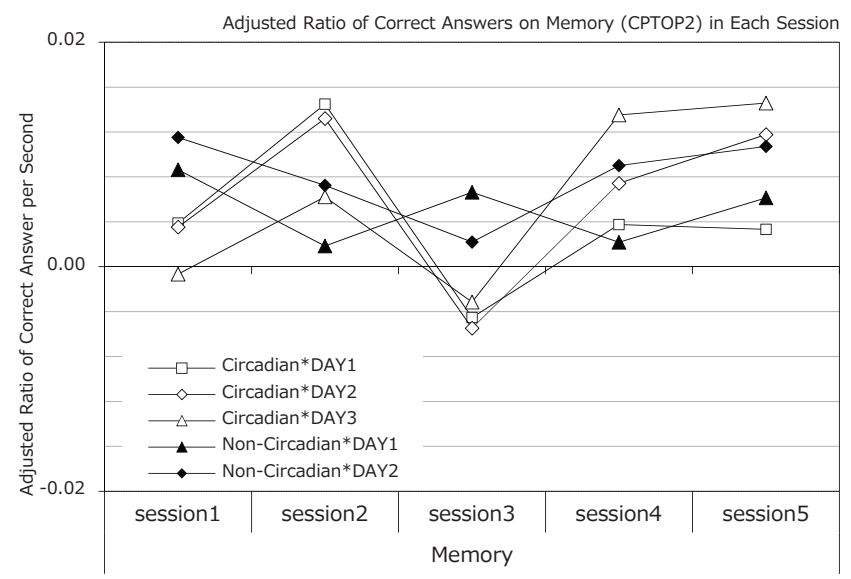

図 8 「記憶(Memory)」課題における成績推移

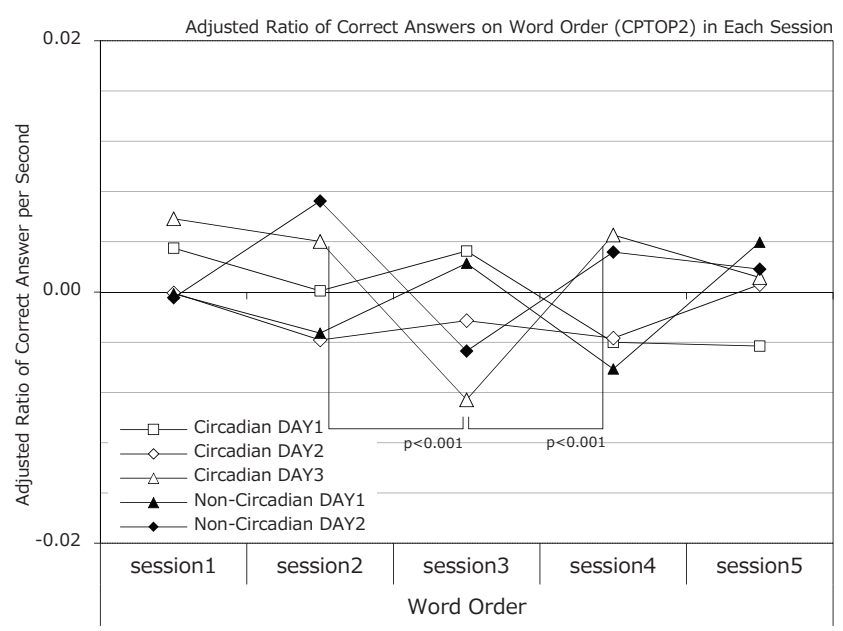

図 9 「語順並心゙替え(Word Order)」における成績推移
ことが考えられる。しかし実験条件・セッションを要因とした分散 分析からは、いずれの要因についても帰無仮説は萧却されなかった。

\subsection{3「語順並べ替え(Word Order)」の成績}

図 9 に「語順並べ替え(Word Order)」の成績の推移を示す。実験 条件・セッションを要因とした分散分析からは、交互作用について のみ帰無仮説が棄却された。単純主効果を確認したのちに行った多 重比較検定の結果からは、サーカディアン条件三日目の Session3 に おける作業成績が、Session2、Session4 の作業成績よりも有意に低 いことが示された（Session2/Session3:p<0.001, Session3/Sessio $\mathrm{n} 4: \mathrm{p}<0.001)$ 。しかしながら、その他のサーカディアン条件において 同様の傾向が確認できなかった。

\section{5 まとめ}

本研究では、昼光照度を制御した休憩室での休款と、作業室で の作業とを交互に繰り返す被験者実験を行い、休㮩中の短時間の 昼光曝露が、執務室での作業成績に及ぼす影響を分析した。休覣 室の照明条件は、サーカディアン条件（昼光曝露あり）と、非サ 一カディアン条件（昼光曝露なし）の二つ。作業室でのパソコン 作業は間に休㮩を挟みつつ一日に 5 セッション。それぞれのセッ ションで「数列穴埋め (Arithmetic)」「記憶 (Memory)」「語順並べ 替え (Word Order)」の 3 種類の作業課題を行った。実験結果から 特に重要なものを取り上げる。

- 瞬目群発の発生頻度は、午前と午後それぞれの最終セッション （11:00-12:00 と 16:00-17:00）において、非サーカディアン条件 よりサーカディアン条件のほうが有意に低い結果となった。サ 一カディアン条件では、この二つの時間帯において覚醒水準が 上昇する傾向にあることが示唆された。

-「数列穴埋め (Arithmetic)」の作業成績は全日程を通して、昼食 後のセッション（13:00-14:00）の成績が、一日の最初のセッシ ヨン（9:30-10:30）と最後のセッション（16:00-17:00）の成績よ りも有意に高い結果となった。

・ サーカディアン条件では、「数列穴埋め (Arithmetic)」の作業成 績が、休頽前よりも休䕀後の方が有意に低くなる時間帯のある ことがわかった。休鄎中の昼光曝露が、休㕰後の作業成績を低 下させてしまう効果を持つことが示唆された。

以上より、本研究の結果からは、休㮩中の短時間の昼光曝露につ いては、特定の時間帯における覚醒水準の上昇」というメリットと ともに、「休憩後の作業成績の低下」というデメリットまでもが示さ れるかたちとなった。昼光利用サーカディアン照明を実際の休㮩空 間へ適用寸るためには、メリットを生かしながら、デメリットをう まく回避する方法を見つけることが必須となる。

リフレッシュアビリティを、休㮩による短期的な疲労回復の性能 と定義するならば、休䕀後の作業成績が低下している時間帯のある ことから、休覣時の昼光曝露は、リフレッシュアビリティを低下さ せているといえる。しかし一日を通してみると、昼光曝露下での休 憩を繰り返すことによって、午前と午後の終盤の覚醒水準を上昇さ せることができており、リフレッシュアビリティが向上していると 捉えることもできる。リフレッシュアビリティを評価指標としてど う定義するかについては、今後さらなる検討が必要であろう。 
なお本論の検証射程は、あくまで 7001x の人工光環境と、20001x の昼光環境との間の効果の比較に制限されるものである。今後は、 昼光と人工光の波長成分の違いに焦点をあてて実験的検証を展開 していくことも必要であろう。

加えて、現実的には、勤務時間中 1 時間おきに 30 分もの休熄をと ることは考えにくい。また毎回同じ場所で昼光曝露にさらされるこ とが、リフレッシュに悪影響を与えていることも考えられる。実際 のオフィスへの導入を推進していくためには、昼光曝露の頻度を減 らす、曝露時間を短くしていく、あるいは昼光暴露のない環境下で の休憩を織り交ぜるなど、より現実の休毠体系に近い条件設定を加 え実用化に向けた検証を重ねていく必要がある。昼光曝露によって 作業成績が低下寸る要因の究明を含めて今後の課題とする。

\section{謝辞}

実験に参加していただいた被験者の方々、実験の準備に協力して いただいた方々に厚く御礼申し上げます。なお、本研究は、日本学 術振興会科学研究費補助金・基盤研究（B）「室内環境が知的生産性 に及ぼす影響と評価にかかわる研究」(代表 : 川瀬貴晴、2008〜2010 年度、課題番号 20360258）の助成を受けたものである。

\section{参考文献}

1）小山恵美：生体リズムと光環境，組織培養工学, Vol.24,No.3, pp.124-127, 1998.

2）片山就司, 伊藤武夫, 野口公喜:「オフィスサーカディアン照明」システム (特 集 松下電工 東京本社ビル), 松下電工技報, No.81, pp.24-29, 2003.3 .

3）伊藤武夫：生体リズムを考慮した高齢者福祉施設・病院の照明, 電気設備学 会誌, Vol.21,No.1, pp.36-39, 2001.1.

4) Mishima, K., Okawa, M., Shimizu, T., Hishikawa, Y.: Diminished Melatonin Secretion in the Elderly Caused by Insufficient Environmental Illumination, Journal of Clinical Endocrinology \& Metabolism, Vol.86,No.1, pp.129-134, 2001.1

5) Crowley, S. J., Lee, C., Tseng, C. Y., Fogg, L. F., Eastman, C. I.: Complete or partial circadian re-entrainment improves performance, alertness, and mood during night-shift work., Sleep, Vol.27,No.6, pp.1077-87, 2004.9.

6) Yoshioka, Y., Kawase, T., Sekikawa, S., Obayashi, F., Terano, M.: Effect of Circadian Lighting System Complemented the Brightness with Daylight on human performance, Proceedings of the 11th International Conference on Human-Computer Interaction, 2005.

7）関川智, 大林史明, 吉岡陽介, 寺野真明, 川瀬貴晴: 昼光利用サーカディア ン照明の実効性, 日本建築学会大会学術講演梗概集 D-1, pp.279-280, 2005.7
8）久米功人，吉岡陽介，川瀬貴晴，関川智，大林史明：昼光利用サーカディア ン照明の照度条件による知的生産性一の影響, 日本建築学会大会学術講演 梗概集 D-1, pp.799-800, 2006.7.

9）吉岡陽介，宗方淳，川瀬貴晴：休款室での短時間の高照度光照射が生体リズ ムに与える影響, 日本建築学会大会学術講演梗概集 E-2, pp.179-180, 2009.7.

10) Heath, G. A., Mendell, M. .: Do Indoor Environments in Schools Influence Student Performance?, A Review of the Literature, Proceedings of Indoor Air 2002, pp.802-807, 2002.

11) Seppanen, O., Fisk, W. J., Lei, Q. H.: Effect of temperature on task performance in office environment, Lawrence Berkeley National Laboratory, 2006.

12) Fisk, W. J., Seppanen, O., Faulkner, D., Huang, J.: Economizer system cost effectiveness: Accounting for the influence of ventilation rate on sick leave, Lawrence Berkeley National Laboratory, 2003.6.

13) Wargocki, P., Wyon, D., Sundell, J.: The effects of outdoor air supply rate in an office on perceived air quality, sick building syndrome (SBS) symptoms and productivity, Indoor Air, pp.222-236, 2000.

14) Barnaby, J. F.: Lighting for productive gains, Lighting Design Application, Vol.10,No.2, pp.20-28, 1980.

15) Hedge, A., Sims, W. R., Becker, F. D.: Effects of lensed-indirect and parabolic lighting on the satisfaction, visual health, and productivity of office workers., Ergonomics, Vol.38,No.2, pp.260-80, 1995.2.

16) 知的創造とワークプレイス: (財) 建築環境・省エネルギー機構, ランダムハウス ジャパン, 2010 .

17) Park, S. J., Tokura, H.: Bright light exposure during the daytime affects circadian rhythms of urinary melatonin and salivary immunoglobulin A., Chronobiology international, Vol.16,No.3, pp.359-371, 1999.5.

18) Takasu, N., Hashimoto, S., Yamanaka, Y., Tanahashi, Y., Yamazaki, A., Honma, S., Honma, K.: Repeated exposures to daytime bright light increase nocturnal melatonin rise and maintain circadian phase in young subjects under fixed sleep schedule., American journal of physiology. Regulatory, integrative and comparative physiology, Vol.291,No.6, pp.1799-1807, 2006.12.

19) Leproult, R., Colecchia, E. F., L'Hermite-Balériaux, M., Van Cauter, E.: Transition from dim to bright light in the morning induces an immediate elevation of cortisol levels., The Journal of clinical endocrinology and metabolism, Vol.86,No.1, pp.151-157, 2001.1.

20) Beck-Friis, J., Borg, G., Wetterberg, L.: Rebound Increase of Nocturnal Serum Melatonin Levels following Evening Suppression by Bright Light Exposure in Healthy Men: Relation to Cortisol Levels and Morning Exposure, Annals of the New York Academy of Sciences, Vol.453,No.1, pp.371-375, 1985.9.

21) Miyagi, K., Shimoda, H., Ishii, H., Enomoto, K., Iwakawa, M., Terano, M.: Development of an Evaluation Method for Office Work Productivity, in Engineering Psychology and Cognitive Ergonomics, Harris, D., Vol.5639, pp.101-110, 2009.7.

22) 保坂良資：まばたき発生パターンを指標とした覚醒水準評価の一方法，人間工 学, Vol.19,No.3, pp.161-167, 1983.

23）下田宏，服部瑤子，冨田和宏，河内美佐，石井裕剛，大林史明，寺野真明， 吉川榮和: オフィスワーカのプロダクティビティ改善のための環境制御法の研究 一プロダクティビティ評価法CPTOPの開発一, ヒューマンインタフェースシンポ ジウム論文集, Vol.2006,pp.1321, 2006.9. 


\title{
EFFECTS OF DAY-LIGHT EXPOSURE IN RESTING SPACE ON AROUSAL LEVEL AND PERFORMANCE IN WORK PLACE
}

\author{
Yohsuke YOSHIOKA* , Jun MUNAKATA** and Takaharu KAWASE** \\ * Assist. Prof., Division of Architecture and Urban Science, Graduate School of Engineering, Chiba University, Dr.Eng. \\ ** Prof., Division of Architecture and Urban Science, Graduate School of Engineering, Chiba University, Dr.Eng.
}

The blight light exposure at the critical times of daytime is an effective treatment method for improving some mental and physical health problems that the disorder of human circadian biological clock causes. In this study, an experiment was performed to clarify the effects of the intermittent daylight exposure in a resting space on arousal level and the task-performance in a work place and the human circadian rhythms.

Twenty healthy young university students participated in this experiment for 5 days after giving informed consent. They maintained a regular sleep-awake schedule beginning from 1 week before the experiment period and kept it throughout the experiment period.

The experimental room was divided in two spaces, the working space and the resting space. The participants spend the daytime of the experimental period alternately in these two spaces, one hour working session in the working space and 30 minutes resting time in the resting space.

In the working space, the intensity of illumination at the desktop was constantly kept at 700lx by the fluorescent lights every time in the experiment period. For the resting space, there were two different lighting conditions, 3 days of the circadian condition and 2 days of non-circadian condition.

In the non-circadian condition, the intensity of illumination on the tabletop was also kept at 700lx by the fluorescent lights. In the circadian condition, in contrast, the intensity of daylight on the center of the tabletop in the resting space was controlled with the window blinds to be within a range from 1600lx to 2200lx during the break in the morning term, and it was gradually decreased to 700lx by closing the window blind slowly after the afternoon term.

The following two measurements were performed for each participant in each working space. For analyzing the arousal levels, the frequency of the blink burst was captured with the precise motion camera arranged on the desktop. For measuring the task performance, the participants were asked to perform on the three different computer tasks in each working session. Those three tasks, "Arithmetic", "Memory" and "Word Order", are selected from a task-set program of CPTOP2.

The experimental results are summarized as follows:

1) During the two term of working sessions, 11:00-12:00 and 16:00-17:00, the arousal levels analyzed from the frequency of the blink burst significantly decreases at the circadian condition more than the non-circadian condition. This result suggest that the daylight exposure in resting space improve the arousal level for work performance in working space.

2) The ratio of correct answer for "Arithmetic" task, one of the three computer task, significantly increase at the middle working session, 13:00-14:00, more than at the first and last working session, 9:30-10:30 and 16:00-17:00, through every condition and every experimental period.

3) At some sessions of the circadian condition, the ratio of correct answer for "Arithmetic" task were significantly decrease after the resting time than before the resting time. The result suggest that the daylight exposure has a negative effect for the task performance after the exposure. 